\title{
HUBUNGAN KEPUASAN KERJA DENGAN PRESTASI KERJA PERAWAT DI INSTALASI RAWAT INAP RUMAH SAKIT ISLAM KLATEN
}

\author{
Sri Hartati, Lina Handayani, Solikhah \\ Fakultas Kesehatan Masyarakat Universitas Ahmad Dahlan
}

\begin{abstract}
Background: Standart evaluation and quality control exIpain that nursery services guarantee a high quality of nursing by involving themselves into quality control in the hospital. Job satisfaction must be created goodly, in order to job morality, disciplined, dedication and job performance can be increased. The employee can work produce or not was depent on motivation, job satisfaction, the level of stress, phisicly condition of job, salary, project of work, aspeck of economy and technics. The aim of this reseach was to know correlation job satisfaction and job performance.

Methods: The study was analytic quantitative with cross sectional method. Data were analyzed quantitatively with Product Moment correlation analyze. The population was all of nurse (110 persons) in the nursery room services at the Klaten Islamic Hospital. The tool of the study was questionaire toward 52 respondents. Sample taken by proportional random sampling.

Result: The result of the study showed that job satisfaction of nurses was on the moderate level reached $(63,5 \%)$. Job performance of nurses was on the good level reache $(78,8 \%)$. There were positive correlation between job satisfaction and job performance, with correlation coefficien $r=0,393$ (on the low level); with $\mathrm{p}=0,004$.

Conclusion: There were positive correlation between job satisfaction and job performance of nurses.
\end{abstract}

Key words: Job satisfaction, job performance, nurse.

\section{PENDAHULUAN}

Keperawatan adalah salah satu profesi di rumah sakit yang berperan penting dalam penyelenggaraan upaya menjaga mutu pelayanan kesehatan di rumah sakit. Pada standar tentang evaluasi dan pengendalian mutu dijelaskan bahwa pelayanan keperawatan menjamin adanya asuhan keperawatan yang bermutu tinggi dengan terusmenerus melibatkan diri dalam program pengendalian mutu di rumah sakit. Peranan perawat sangat penting karena sebagai ujung tombak baik tidaknya mutu pelayanan kesehatan yang diberikan kepada pasien. Perawat merupakan salah satu profesi di rumah sakit dengan jumlah yang paling dominan dan paling lama kontak atau berhubungan (berinteraksi) dengan pasien di pelayanan rawat inap selama 24 jam. ${ }^{1}$

Ada banyak faktor yang mempengaruhi prestasi kerja karyawan. Karyawan akan bekerja dengan produktif atau tidak tergantung pada motivasi, kepuasan kerja, tingkat stres, kondisi fisik pekerjaan, sistem kompensasi, desain pekerjaan, dan aspek-aspek ekonomis, teknis serta keperilakuan lainnya. Departemen personalia atau manajemen harus senantiasa memonitor kepuasan kerja, karena hal itu mempengaruhi tingkat absensi, perputaran tenaga kerja, semangat kerja, keluhan-keluhan, dan masalahmasalah personalia vital lainnya. ${ }^{2}$

Berdasarkan observasi yang telah dilakukan pada tanggal 3 Mei 2008 di Rumah Sakit Islam Klaten, perawat menganggap pengembangan karier untuk perawat dirasakan masih terbatas. Ada perawat yang menyatakan kurangnya kerja sama dengan rekan sekerja. Masih ada perawat yang sering datang terlambat dan seringkali ada perawat yang meninggalkan pekerjaannya. hal tersebut menunjukkan kedisiplinan dan tanggung jawab perawat terhadap pekerjaannya masih rendah. Kurangnya 
kerjasama antar perawat dan rendahnya disiplin akan mempengaruhi prestasi kerja perawat. Menurut Bagian personalia, dalam tiga tahun terakhir ini ada 13 perawat yang pindah kerja (turn over) dari total 158 perawat di Rumah Sakit Islam Klaten. Alasan pindah kerja antara lain karena perawat ada yang lebih memilih untuk berwirausaha, dan alasan lain yang tidak jelas. Pindah kerja (turn over) merupakan salah satu indikator kepuasan kerja.

Tujuan umum penelitian ini adalah Mengetahui hubungan kepuasan kerja dengan prestasi kerja perawat di Instalasi Rawat Inap Rumah Sakit Islam Klaten. Tujuan Khusus penelitian ini adalah 1)Mengetahui tingkat kepuasan kerja perawat di Instalasi Rawat Inap Rumah Sakit Islam Klaten. 2)Mengetahui tingkat prestasi kerja perawat di Instalasi Rawat Inap Rumah Sakit Islam Klaten. 3)Mengetahui hubungan kepuasan kerja dengan prestasi kerja perawat di Instalasi Rawat Inap Rumah Sakit Islam Klaten.

\section{METODE PENELITIAN}

Jenis penelitian ini adalah analitik kuantitatif menggunakan rancangan cross sectional. Rancangan cross sectional adalah rancangan yang pengukuran variabelvariabelnya dilakukan hanya satu kali, pada satu saat ${ }^{3}$.

\section{a. Populasi dan Subyek Penelitian}

Populasi dalam penelitian ini adalah perawat yang bekerja di instalasi rawat inap Rumah Sakit Islam Klaten, yang terdiri dari perawat lulusan SPK, DIII keperawatan, dan S1 Keperawatan yang berjumlah 110 perawat.

Kriteria inklusi dalam penelitian ini adalah :

1) Pendidikan SPK, D III Keperawatan, S1 Keperawatan

2) Lama bekerja lebih dari 5 tahun

3) Perawat yang tidak sedang cuti atau sakit pada waktu penelitian dilakukan dan tidak sedang menjalani pendidikan

4) Bersedia menjadi responden

Kriteria eksklusi :

1) Perawat yang bekerja kurang dari 5 tahun

2) Perawat yang sedang cuti

3) Perawat yang sedang menjalani pendidikan

4) Tidak bersedia menjadi responden

Pengambilan sampel dalam penelitian ini dilakukan secara proporsional dan acak. Teknik pengambilan sampel menggunakan Proportional random sampling. Untuk mendapatkan sampel dihitung dengan rumus Lemeshow ${ }^{4}$ didapatkan jumlah sampel 52 perawat.

Pengumpulan data menggunakan kuesioner untuk mengetahui hubungan antara kepuasan kerja dengan prestasi kerja perawat di Instalasi Rawat Inap Rumah Sakit Islam Klaten. Kuesioner sebelum digunakan untuk mengumpulkan data terlebih dahulu dilakukan uji validitas dan reliabilitas di Rumah Sakit Daerah Panembahan Senopati Bantul.

Hasil uji validitas, untuk variabel kepuasan kerja, ada 36 butir pertanyaan dan 8 butir dinyatakan gugur. Variabel prestasi kerja, ada 48 butir pertanyaan, 14 butir pertanyaan dinyatakan gugur. Hasil uji Reliabilitas dari seluruh butir pertanyaan variabel kepuasan kerja dan prestasi kerja dapat dinyatakan seluruhnya handal atau sudah reliabel dan didapatkan nilai Alpha Cronbach >0,361.

Tahap analisis statistik dilakukan menggunakan analisis univariat dan bivariat. Analisis bivariat menggunakan uji korelasi Pearson Product Moment untuk

KES MAS Vol. 5, No. 1, Januari $2011: 1$ - 67 
melihat apakah ada hubungan antara kepuasan kerja dengan prestasi kerja perawat di Instalasi Rawat Inap Rumah Sakit Islam Klaten.

\section{HASIL PENELITIAN DAN PEMBAHASAN}

\section{a. Hasil Penelitian}

1) Hasil Analisis Univariat

Setelah data ditabulasi, dikoding, dan dianalisis dengan statistik deskriptif, dapat dideskripsikan bahwa karakteristik responden berdasarkan kepuasan kerja dapat dilihat pada Tabel 1.

Tabel 1. Karakteristik Responden Berdasarkan Kepuasan Kerja Perawat di Rumah Sakit Islam Klaten Tahun 2008

\begin{tabular}{c|l|c|c}
\hline Karakteristik Responden & Kategori & Jumlah & Persentase (\%) \\
\hline Kepuasan Kerja & Rendah & 0 & 0 \\
& Sedang & 33 & 63,5 \\
& Tinggi & 19 & 36,5 \\
\hline
\end{tabular}

Tabel 1 menunjukkan kepuasan kerja perawat sebagian besar berada pada kategori sedang yaitu sebanyak 33 responden $(63,5 \%)$.

Tabel 2. Karakteristik Responden Berdasarkan Dimensi Kepuasan Kerja Perawat di Rumah Sakit Islam Klaten Tahun 2008

\begin{tabular}{l|l|c|c}
\hline Karakteristik Responden & Kategori & Jumlah & Persentase (\%) \\
\hline Promosi & Rendah & 1 & 1,9 \\
& Sedang & 29 & 55,8 \\
& Tinggi & 22 & 42,3 \\
\hline \multirow{2}{*}{ Gaji } & Rendah & 5 & 9,6 \\
& Sedang & 29 & 55,8 \\
& Tinggi & 18 & 34,6 \\
\hline \multirow{2}{*}{ Supervisi } & Rendah & 0 & 0 \\
& Sedang & 26 & 50 \\
& Tinggi & 26 & 50 \\
\hline Teman sekerja & Rendah & 0 & 0 \\
& Sedang & 9 & 17,3 \\
& Tinggi & 43 & 82,7 \\
\hline Pekerjaan & Rendah & 0 & 0 \\
& Sedang & 31 & 59,6 \\
& Tingi & 21 & 40,4 \\
\hline
\end{tabular}

Kepuasan kerja perawat dimensi promosi mayoritas berada pada kategori sedang yaitu sebanyak 29 responden $(55,8 \%)$. Kepuasan kerja perawat pada dimensi gaji mayoritas pada kategori sedang sebanyak 29 responden $(55,8 \%)$. Kepuasan kerja dimensi supervisi sebagian berada pada kategori sedang dan tinggi masing-masing 26 responden (50\%). Kepuasan kerja perawat pada dimensi teman sekerja sebagian besar berada pada kategori tinggi, yaitu sebanyak 43 responden $(82,7 \%)$. Kepuasan kerja dimensi pekerjaan sebagian besar berada pada kategori sedang, yaitu sebanyak 31 responden $(59,6 \%)$. 
Tabel 3. Karakteristik Responden Berdasarkan Prestasi Kerja Perawat di Rumah Sakit Islam Klaten Tahun 2008

\begin{tabular}{l|c|c}
\hline \multicolumn{1}{c|}{ Prestasi Kerja } & Jumlah & Persentase (\%) \\
\hline Kurang baik & 0 & 0 \\
Sedang/cukup baik & 11 & 21,2 \\
Baik & 41 & 78,8 \\
\hline \multicolumn{1}{c|}{ Jumlah } & 52 & 100 \\
\hline
\end{tabular}

Tabel 3 menunjukkan bahwa prestasi kerja perawat sebagian besar perawat di Instalasi Rawat Inap Rumah Sakit Islam Klaten berkategori baik yaitu sebanyak 41 responden $(78,8 \%)$.

Tabel 4. Karakteristik Responden Berdasarkan Dimensi Prestasi Kerja Perawat di Rumah Sakit Islam Klaten Tahun 2008

\begin{tabular}{|c|c|c|c|}
\hline Karakteristik Responden & Kategori & Jumlah & Persentase (\%) \\
\hline Kualitas kerja & $\begin{array}{l}\text { Kurang Baik } \\
\text { Sedang/cukup baik } \\
\text { Baik }\end{array}$ & $\begin{array}{c}0 \\
3 \\
49\end{array}$ & $\begin{array}{c}0 \\
5,8 \\
94,2\end{array}$ \\
\hline Keandalan & $\begin{array}{l}\text { Kurang Baik } \\
\text { Sedang/cukup baik } \\
\text { Baik }\end{array}$ & $\begin{array}{c}0 \\
12 \\
40\end{array}$ & $\begin{array}{c}0 \\
23,1 \\
76,9\end{array}$ \\
\hline Inisiatif & $\begin{array}{l}\text { Kurang baik } \\
\text { Sedang/cukup baik } \\
\text { Baik }\end{array}$ & $\begin{array}{c}0 \\
12 \\
40\end{array}$ & $\begin{array}{c}0 \\
23,1 \\
76,9\end{array}$ \\
\hline Kerjasama & $\begin{array}{l}\text { Kurang baik } \\
\text { Sedang/cukup baik } \\
\text { Baik }\end{array}$ & $\begin{array}{c}0 \\
17 \\
35\end{array}$ & $\begin{array}{c}0 \\
32,7 \\
67,3\end{array}$ \\
\hline Komunikasi & $\begin{array}{l}\text { Kurang baik } \\
\text { Sedang/cukup baik } \\
\text { Baik }\end{array}$ & $\begin{array}{c}0 \\
11 \\
41\end{array}$ & $\begin{array}{c}0 \\
21,2 \\
78,8\end{array}$ \\
\hline Kedisiplinan & $\begin{array}{l}\text { Kurang baik } \\
\text { Sedang/cukup baik } \\
\text { Baik }\end{array}$ & $\begin{array}{c}0 \\
2 \\
50\end{array}$ & $\begin{array}{c}0 \\
3,8 \\
96,2\end{array}$ \\
\hline Tangung_jawab & $\begin{array}{l}\text { Kurang baik } \\
\text { Sedang/cukup baik } \\
\text { Baik }\end{array}$ & $\begin{array}{c}0 \\
9 \\
43\end{array}$ & $\begin{array}{c}0 \\
17,3 \\
82,7\end{array}$ \\
\hline Kepribadian & $\begin{array}{l}\text { Kurang baik } \\
\text { Sedang/cukup baik } \\
\text { Baik }\end{array}$ & $\begin{array}{c}0 \\
1 \\
51\end{array}$ & $\begin{array}{c}0 \\
1,9 \\
98,1\end{array}$ \\
\hline Kepemimpinan & $\begin{array}{l}\text { Kurang baik } \\
\text { Sedang/cukup baik } \\
\text { Baik }\end{array}$ & $\begin{array}{c}0 \\
15 \\
37\end{array}$ & $\begin{array}{c}0 \\
28,8 \\
71,2\end{array}$ \\
\hline Komitmen/ Loyalitas & $\begin{array}{l}\text { Kurang baik } \\
\text { Sedang/cukup baik } \\
\text { Baik }\end{array}$ & $\begin{array}{c}0 \\
12 \\
40\end{array}$ & $\begin{array}{c}0 \\
23,1 \\
76,9\end{array}$ \\
\hline Kejujuran & $\begin{array}{l}\text { Kurang baik } \\
\text { Sedang/cukup baik } \\
\text { Baik }\end{array}$ & $\begin{array}{c}0 \\
7 \\
45\end{array}$ & $\begin{array}{c}0 \\
13,5 \\
86,5\end{array}$ \\
\hline
\end{tabular}

Tabel 4 menunjukkan tingkat prestasi kerja perawat pada beberapa dimensi. Prestasi kerja perawat dimensi kualitas kerja sebagian besar sudah berkategori baik, yakni sebanyak 49 responden (94,5\%). Dimensi keandalan, sebagian besar perawat sudah berkategori baik sebanyak 40 responden 
$(76,9 \%)$. Prestasi kerja dimensi inisiatif, sebagian besar responden sudah berkategori baik, yaitu sebanyak 40 responden $(76,9 \%)$. Tingkat kerjasama perawat, sebagian besar responden sudah berkategori baik, yaitu sebanyak 35 responden $(67,3 \%)$. Sub variabel komunikasi perawat, sebagian besar berkategori baik yaitu sebanyak 41 responden $(78,8 \%)$. Tingkat kedisiplinan perawat sebagian besar berkategori baik, yaitu sebanyak 50 responden $(96,2 \%)$. Tanggung jawab perawat sebagian besar berkategori baik, yaitu sebanyak 43 responden $(82,7 \%)$. Kepribdian perawat sebagian besar berkategori baik, yaitu sebanyak 51 responden $(98,1 \%)$. Dimensi kepemimpinan perawat, sebagian besar berkategori baik, yaitu sebanyak 37 responden $(71,2 \%)$. Tingkat komitmen/loyalitas perawat, sebagian besar sudah berkategori baik yaitu sebanyak responden $(76,9 \%)$. Kejujuran perawat, sebagian besar responden sudah berkategori baik, yaitu sebanyak 45 responden $(86,5 \%)$.

2) Hasil Analisis Bivariat

Analisis bivariat pada penelitian ini menggunakan statistik parametik, yaitu uji korelasi Product Moment untuk melihat hubungan antara variabel bebas (kepuasan kerja) dengan variabel terikat (prestasi kerja). Confidence Level yang digunakan dalam penelitian ini adalah 95\% dengan nilai p sebesar 0,05.

Tabel 5. Hubungan Kepuasan Kerja dengan Prestasi Kerja Perawat di Rumah Sakit Islam Klaten Tahun 2008

\begin{tabular}{ccc}
\hline Variabel & \multicolumn{2}{c}{ Prestasi Kerja } \\
\hline & $\mathrm{r}$ & $\operatorname{Sig}(\mathrm{p})$ \\
\hline Kepuasan Kerja & 0,393 & 0,004 \\
\cline { 2 - 3 }
\end{tabular}

Tabel 5 menunjukkan hubungan kepuasan kerja dengan prestasi kerja dengan koefisien korelasi $r$ sebesar $=0,393$ (tingkat korelasi rendah) dengan $p=$ 0,004 lebih kecil dari $(0,05)$. Nilai $p$ kurang dari taraf signifikan yang ditentukan $5 \%$, maka Ha diterima dan Ho ditolak maka disimpulkan bahwa ada hubungan yang positif (tingkat korelasi rendah) dan signifikan antara kepuasan kerja dengan prestasi kerja perawat di Instalasi Rawat Inap Rumah Sakit Islam Klaten.

\section{b. Pembahasan}

1) Tingkat Kepuasan Kerja Perawati Instalasi Rawat Inap Rumah Sakit Islam Klaten.

Berdasarkan hasil penelitian dapat dilihat bahwa tingkat kepuasan kerja perawat di Instalasi Rawat Inap Rumah Sakit Islam Klaten adalah 33 responden $(63,5 \%)$ berada pada kategori sedang. Secara umum kepuasan kerja perawat di Instalasi Rawat Inap Rumah Sakit Islam Klaten berada pada kategori sedang. Sebagian besar responden $(55,8 \%)$ menyatakan kepuasan kerja dimensi promosi berada pada kategori sedang. Promosi pengembangan karie yang sudah dilakukan pihak Rumah Sakit antara lain untuk perawat yang telah bekerja lebih dari 3 tahun diusulkan untuk meningkatkan kompetensi dengan diberi pelatihan sesuai kompetensinya. Perawat yang telah bekerja lebih dari 5 tahun diusulkan untuk menjadi ketua tim, kepala ruang atau pengelola keperawatan.

Berdasarkan analisis univariat, untuk dimensi kompensasi/gaji sebagian besar responden menyatakan kepuasan terhadap dimensi gaji berada pada kategori sedang yaitu sebanyak 29 responden $(55,8 \%)$. Hal ini berarti responden menilai gaji yang diterimanya dirasakan sudah cukup sesuai dengan 
kerja yang sudah dilakukan. Kepuasan kerja dimensi supervisi, sebagian responden menyatakan cukup puas (kategori sedang) sebanyak 26 responden $(50 \%)$, dan sisanya menyatakan puas (kategori tinggi). Artinya secara umum responden merasa puas dengan kemampuan teknis dan manajerial penyelia dalam memberikan pengarahan dan perhatian terhadap karyawan. Sebagian besar responden menyatakan puas (kategori tinggi) yaitu sebanyak 43 responden $(82,7 \%)$ pada dimensi kepuasan terhadap teman sekerja. Hal ini berarti teman sekerja sudah sangat mendukung dan memberikan perhatian menyenangkan dan secara teknis mampu melaksanakan tugas-tugas. Sedangkan untuk dimensi pekerjaan, sebagian besar responden menyatakan kepuasan kerja pada kategori sedang yaitu sebanyak 31 responden $(59,6 \%)$. Hal ini berarti pekerjaan sebagai perawat dinilai cukup memberikan kesempatan untuk belajar dan kesempatan menerima tanggung jawab.

2) Tingkat Prestasi Kerja Perawat di Rumah Sakit Islam klaten

Prestasi kerja adalah hasil kerja secara kualitas dan kuantitas yang dicapai seorang pegawai dalam melaksanakan tugasnya sesuai dengan tanggung jawab yang diberikan kepadanya. Berdasarkan hasil penelitian, dapat dilihat bahwa tingkat prestasi kerja perawat di Instalasi Rawat Inap Rumah Sakit Islam Klaten adalah 41 responden $(78,2 \%)$ berada pada kategori baik. Secara umum prestasi kerja perawat di Instalasi Rawat Inap Rumah Sakit Klaten berada pada kategori baik.

Tingkat kualitas kerja perawat berada pada kategori baik. Hal ini berarti perawat sudah melaksanakan pekerjaannya dengan memperhatikan kelengkapan administrasi pekerjaan, tertib saat bekerja dan melakukan perawatan peralatan kerja sesuai ketentuan yang berlaku di Rumah Sakit Islam Klaten. Tingkat keandalan perawat sebagian besar berkategori baik. Hal ini menunjukkan perawat berperilaku ulet, pantang menyerah, serius dan berkonsntrasi dalam bekerja. Dimensi inisiatif perawat, sebagian besar berada pada kategori baik. Hal ini menunjukkan perawat mampu memberikan usul atau saran untuk mengatasi permasalahan dalam bekerja, serta mampu mengetahui dan memahami permasalahan di lingkungan kerja.

Kerjasama antar perawat di Rumah Sakit Islam sudah baik. Hal ini dapat diartikan perawat telah mampu bekerja secara aktif, tidak malu meminta bantuan dan bertanya kepada rekan sekerja, serta memahami dan melaksanakan tugasnya dengan baik bersama rekan sekerjanya. Prestasi kerja perawat untuk dimensi komunikasi sudah baik. Ini berarti perawat mampu menyampaikan pesan dengan jelas, mudah dipahami dan ditindak lanjuti, mampu berkomunikasi dengan baik kepada pelanggan. Tingkat kedisiplinan perawat di Rumah Sakit Islam Klaten berada pada kategori baik. Artinya perawat sudah mematuhi peraturan yang berlaku dalam bekerja, mengetahui hak dan kewajibannya dalam bekerja, misalnya selalu memakai seragam kerja lengkap dan menggunakan alat pelindung diri sesuai ketentuan, masuk kerja tepat waktu.

Dimensi tanggung jawab perawat berada pada kategori baik. Artinya perawat telah bertanggung jawab atas pekerjaannya, hasil kerjanya, sarana dan prasarana yang digunakan. Perawat sudah melaksanakan tugas pokok dan tugas tambahan yang diberikan oleh Rumah Sakit. Perawat tidak melakukan perbuatan yang merugikan Rumah Sakit. Dimensi kepribadian perawat berada pada kategori baik. Kepribadian perawat meliputi sikap yang baik, perilaku yang sopan, serta berpenampilan simpatik dan wajar. Perawat telah bersikap sopan dan santun terhadap orang lain. Perawat sudah berpenampilan rapi dan rajin, serta selalu memberikan senyum, salam, dan sapa terhadap pasien. Komitmen atau loyalitas perawat di Rumah Sakit Islam Klaten berkategori baik. Artinya

KES MAS Vol. 5, No. 1, Januari $2011: 1$ - 67 
perawat setia terhadap pekerjaanya dan organisasi. Tingkat prestasi kerja perawat pada dimensi kejujuran berkategori baik. Hal ini dapat dilihat dari perilaku perawat antara lain, tidak memanipulasi data atau laporan, selalu berkata jujur dan tidak berdalih.

3) Hubungan Kepuasan Kerja dengan P restasi Kerja Perawat di Rumah Sakit Islam Klaten.

Hasil analisis bivariat menunjukkan bahwa ada hubungan positif dan signifikan antara kepuasan kerja dengan prestasi kerja perawat di Instalasi Rawat Inap Rumah Sakit Islam Klaten. Hasil ini ditunjukkan dengan koefisien korelasi Product Moment pada variabel kepuasan kerja sebesar $r=0,393$ yang berarti korelasi yang rendah dengan $p=0,004$.

Hasil penelitian ini sesuai dengan hasil penelitian $\operatorname{Rahman}^{5}$ yang menyatakan ada hubungan positif dan signifikan antara kepuasan kerja dengan kinerja pegawai administrasi di Rumah Sakit Daerah Raden Mattaher Propinsi Jambi. Semakin tinggi kepuasan kerja seseorang akan mempengaruhi tingginya tingkat kinerja seseorang. Hamdana ${ }^{6}$ juga menyatakan ada hubungan yang signifikan antara kepuasan kerja dengan kinerja karyawan bagian sekretariat di Rumah Sakit Grhasia Yogyakarta. Semakin tinggi kepuasan kerja karyawan, maka akan semakin tinggi kinerja karyawan. Semakin rendah kepuasan kerja, maka akan semakin rendah kinerja karyawan. Penelitian yang dilakukan Muzinu $\mathrm{dkk}^{7}$ juga menyatakan kepuasan kerja mempunyai pengaruh positif dan signifikan terhadap prestasi kerja karyawan PT. Bosowa Berlian Motor Makassar. Artinya semakin tinggi kepuasan kerja karyawan, maka akan semakin tinggi pula prestasi kerja karyawan.

Hasil penelitian Almigo ${ }^{8}$ menyatakan terdapat hubungan yang positif dan signifikan antara kepuasan kerja dengan produktivitas kerja karyawan PT. Pupuk Sriwijaya, dengan koefisien korelasi $r=0,252 ; p=0,011$. Artinya semakin tinggi kepuasan kerja, maka akan semakin tinggi produktivitas karyawan. Penelitian ini juga sesuai dengan hasil penelitian Lahida $\mathrm{dkk}^{9}$, yang menyatakan ada pengaruh yang bermakna antara persepsi sistem kompensasi non moneter terhadap produktivitas kerja dokter spesialis tamu di Rumah Sakit Panti Rapih. Kompensasi merupakan salah satu dimensi kepuasan kerja. Untuk meningkatkan kepuasan kinerja perawat suatu rumah sakit harus dapat menciptakan iklim kerja atau iklim organisasi yang nyaman bagi praktik asuhan keperawatan. Hasil penelitian Tumbol $\mathrm{dkk}^{10}$ juga menyatakan bahwa sub variabel kepuasan kerja berhubungan positif dan signifikan terhadap pelayanan prososial perawat di Rumah Sakit Umum daerah DR. Sam Ratulangi Tondano. Hubungan yang bervariasi menunjukkan bahwa perilaku pelayanan prososial terwujud bila ada kepuasan kerja. Hasil penelitian Nurjahjani ${ }^{11}$ mengungkapkan bahwa ada hubungan yang positif dan signifikan antara variabel imbalan finansial, imbalan interpersonal, dan promosi dengan prestasi kerja karyawan. Imbalan finansial merupakan variabel yang paling dominan mempengaruhi kepuasan kerja, dengan tingkat keeratan hubungan sebesar $48,1 \%$.

Hasil penelitian ini menunjukkan nilai koefisien korelasi $r$ adalah 0,393 yang berarti hubungan antara kepuasan kerja dengan dengan prestasi kerja perawat di Instalasi Rawat Inap Rumah Sakit Islam Klaten berada pada tingkat korelasi yang rendah/lemah. Hal ini sesuai dengan pendapat Handoko ${ }^{2}$, bahwa secara historis sering dianggap bahwa para karyawan yang mendapatkan kepuasan kerja akan melaksanakan pekerjaan dengan baik. Dalam banyak kasus, memang sering ada hubungan yang positif antara kepuasan tinggi dan prestasi kerja tinggi, tetapi tidak selalu cukup kuat dan berarti signifikan. Secara umum kepuasan kerja perawat berada pada tingkat sedang, akan tetapi prestasi 
kerja perawat secara umum berada pada kategori tinggi. Hal ini dapat terjadi dimungkinkan karena faktor pendorong perawat untuk berprestasi tidak hanya disebabkan oleh kepuasan kerja saja, tetapi dipengaruhi oleh faktor lain misalnya karakteristik individu, misalnya latar belakang pendidikan, masa kerja yang sudah lama ataupun faktor motivasi dalam diri perawat, ataupun pengaruhi oleh faktor lain yang tidak diteliti dalam penelitian ini.

\section{SIMPULAN DAN SARAN}

\section{a. Simpulan}

Berdasarkan hasil analisis dan pembahasan tentang hubungan kepuasan kerja dengan prestasi kerja perawat di Instalasi rawat Inap Rumah Sakit Islam Klaten diperoleh kesimpulan bahwa:

1) Kepuasan kerja perawat di Instalasi Rawat Inap Rumah Sakit Islam Klaten mayoritas pada kategori sedang sebanyak 33 responden $(63,5 \%)$.

2) Prestasi kerja perawat di Instalasi Rawat Inap Rumah Sakit Islam Klaten mayoritas pada kategori baik sebanyak 41 responden $(78,8 \%)$.

3) Ada hubungan yang positif dan signifikan antara kepuasan kerja dengan prestasi kerja perawat di Instalasi Rawat Inap Rumah Sakit Islam Klaten. ( $r=0,393$ dan $p$ $=0,004)$.

b. Saran

1) Bagi perawat di Rumah Sakit Islam Klaten

Mempertahankan prestasi kerja sesuai harapan rumah sakit, antara lain dengan mengikuti pendidikan dan pelatihan-pelatihan yang di selenggarakan rumah sakit, disiplin dalam bekerja dan mematuhi peraturan yang ada di Rumah Sakit Islam Klaten.

2) Bagi Direktur Rumah Sakit Islam Klaten

Mengupayakan untuk meningkatkan kepuasan kerja perawat agar perawat lebih berprestasi kerja lebih baik. Hal ini dapat diupayakan dengan memberikan kesempatan pada perawat untuk pengembangan sumber daya perawat, dengan pelatihan maupun jenjang pendidikan yang lebih tinggi serta meningkatkan jasa pelayanan keperawatan.

3) Untuk Bagian Keperawatan Rumah Sakit Islam Klaten

Pihak Bagian Keperawatan diharapkan untuk lebih memperhatikan faktor yang mempengaruhi kepuasan kerja perawat dan prestasi kerja perawat antara lain dengan menciptakan iklim dan lingkungan kerja yang mendukung kinerja perawat, memberikan pelatihan sesuai kebutuhan perawat, dan memberikan kesempatan kepada perawat untuk mengembangkan diri agar dapat meningkatkan prestasi kerja perawat.

4) Bagi peneliti lain

Diharapkan dalam penelitian selanjutnya untuk meneliti variabel-variabel lain yang belum diteliti dalam penelitian ini, untuk lebih mengetahui faktor -faktor apa saja yang mungkin dapat meningkatkan prestasi kerja bagi perawat di Rumah Sakit Islam Klaten. Akan lebih baik jika penelitian tentang kepuasan dan prestasi kerja dilakukan dengan metode kualitatif.

\section{DAFTAR PUSTAKA}

1. Aditama, T.Y., Manajemen Administrasi Rumah Sakit, Cetakan Kedua, Universitas Indonesia, Jakarta, 2004

KES MAS Vol. 5, No. 1, Januari $2011: 1$ - 67 
2. Handoko, T.H., Manajemen Personalia dan Sumber Daya Manusia, Edisi Kedua, BPFE, Yogyakarta, 2001

3. Notoatmodjo, S., Metode Penelitian Kesehatan, Rineka Cipta, Jakarta, 2005

4. Lemeshow, Hosmer Jr, D.W., Klar, J dan Lwanga, S.K., Besar Sampel Dalam Penelitian Kesehatan, Gajah Mada University Press, Yogyakarta, 1997

5. Rahman, A., Hubungan Kepuasan dengan Kinerja Pegawai Administrasi di Rumah Sakit Daerah Raden Mattaher Propinsi Jambi, Tesis, Magister Manajemen Rumah Sakit, Universitas Gadjah Mada Yogyakarta, 2005

6. Hamdana, Hubungan Kepuasan Kerja Dengan Kinerja Karyawan Bagian Sekretariat Rumah Sakit Grhasia Yogyakarta, Skripsi, FKM UAD, Yogyakarta, 2007

7. Muzinu, M., Almaida, A., Hubungan Antara Motivasi, Kepuasan Kerja dan Prestasi Kerja Karyawan PT. Bosowa Berlian Motor Makassar, Artikel Penelitian, Lembaga Penelitian Universitas Hasanudin Makassar, 2006

8. Almigo, Hubungan Antara Kepuasan Kerja Dengan Produktivitas Kerja Karyawan, Jurnal Psikologi vol 1, No 1, 2004, Universitas Bina Darma, Palembang, 2004

9. Lahida, M. A.S., Kusnanto, H., Hendratini, J., Pengaruh Persepsi Sistem Kompensasi Non Moneter Terhadap Produktivitas Dokter Spesialis Tamu Di Rumah Sakit Panti Rapih, Jurnal Manajemen Pelayanan Kesehatan, Vol 03/No 02/ 2000, 2000

10. Tumbol, A., Sanusi, R., Hubungan Keadilan di Tempat Kerja dan Kepuasan Kerja Dengan Perilaku Pelayanan Prososial Perawat Di Rumah Sakit Umum Daerah DR. Sam Ratulangi Tondano, Jurnal Manajemen Pelayanan Kesehatan, Vol 04/ No 04/2001, 2001

11. Nurjahjani, F, Pengaruh Imbalan Ekstrinsik Terhadap Prestasi Kerja, Jurnal Ekonomi Modernisasi, Vol 03/No 01 2007, 2007 